DOI $10.31489 / 2020 \mathrm{M} 4 / 92-100$

UDC 517.528

\author{
B.T. Kalimbetov*, A.N. Temirbekov, B.I. Yeskarayeva
}

H.A. Yasawi International kazakh-turkish University, Turkestan, Kazakhstan

(E-mail: burkhan.kalimbetov@ayu.edu.kz, alisher.temirbekov@ayu.edu.kz,bakytgul.yeskarayeva@ayu.edu.kz)

\title{
Internal boundary layer in a singularly perturbed problem of fractional derivative
}

\begin{abstract}
This paper is devoted to the study of internal boundary layer. Such motions are often associated with effect of boundary layer, i.e. low flow viscosity affects only in a narrow parietal layer of a streamlined body, and outside this zone the flow is as if there is no viscosity - the so-called ideal flow. Number of exponentials in the boundary layer is determined by the number of non-zero points of the limit operator spectrum. In the paper we consider the case when spectrum of the limit operator vanishes at the point To study the problem the Lomov regularization method is used. The original problem is regularized and the main term of asymptotics of the problem solution is constructed as the low viscosity tends to zero. Numerical results of solutions are obtained for different values of low viscosity.
\end{abstract}

Keywords: singular perturbation, small parameter, regularization, spectrum stability, asymptotic convergence.

\section{Introduction}

A mathematical model of motion of a viscous flow, where a non-uniform transition from one physical characteristic to another occurs, is described by various differential equations with large or small parameters, which are responsible for non-uniformity of the transition. If we consider the self-made flows, then the Navier-Stokes motion equations and the continuity equation are reduced to ordinary differential equations. In addition, if we introduce a small positive parameter then the motion equation will have a small parameter at the highest derivative. Such an equation is called singularly perturbed. Solution of singularly perturbed differential equations is fundamentally different from a solution of ordinary differential equations with a small parameter. Solution of such equations has an area of rapid change of the function, which is located, as a rule, in a neighborhood of one (or two) boundary points of the problem. Such an area of rapid change of function is called area of mathematical boundary layer. Location of the mathematical boundary layer coincides with hydrodynamic boundary layer. Thickness of the boundary layer depends on size of the small parameter, and as the small parameter decreases, the thickness of the boundary layer also decreases. The domain of integration is divided into the external (outside the boundary layer) and the internal (inside the boundary layer). A solution of the singularly perturbed equation is sought as a solution suitable for the external a domain which is then refined in neighborhood of a boundary point where the boundary layer is located [1]. A problem with an internal boundary layer does not belong to the number of standard problems in the singular perturbations theory. This is due to the fact that value of a small parameter is singular for a singularly perturbed equation (see, for example, the equation (2)). In these cases, it is habitually to talk about a "singular point". The singular point gives rise to a double dependence of the solution on singular and regular. We will illustrate this fact with the following specific example - the Cauchy problem for an ordinary differential equation of the second order [2]:

$$
\begin{gathered}
\varepsilon^{2} \ddot{y}(t, \varepsilon)+\varepsilon\left(\lambda_{1}(t)+\lambda_{2}(t)\right) \dot{y}(t, \varepsilon)+\lambda_{1}(t) \lambda_{2}(t) y(t, \varepsilon)=h(t) \\
y(0, \varepsilon)=y^{0}, \dot{y}(0, \varepsilon)=y^{1}
\end{gathered}
$$

* Corresponding author.

E-mail: burkhan.kalimbetov@ayu.edu.kz 
where $\varepsilon>0$ is a low viscosity, for mathematics it is a small dimensionless parameter; $y(t, \varepsilon)$ is a desired function; function $h(t)$ is a given known function, $y^{0}, y^{1}$ are known constants. It is necessary to study the problem as $\varepsilon \rightarrow+0$.

Let functions $\lambda_{1}(t), \lambda_{2}(t)$ satisfy the following spectrum stability conditions:

1) $\lambda_{i}(t) \neq 0, i=1,2$

2) $\lambda_{1}(t) \neq \lambda_{2}(t) \forall t \in[0, T]$.

In this case structure of a solution of the problem (1) will be as follows:

$$
\begin{aligned}
y(t, \varepsilon) & =e^{\frac{1}{\varepsilon} \int_{0}^{t} \lambda_{1}(x) d x}\left[y_{10}(t)+\varepsilon y_{11}(t)+\ldots\right]+ \\
& +e^{\frac{1}{\varepsilon} \int_{0}^{t} \lambda_{2}(x) d x}\left[y_{20}(t)+\varepsilon y_{21}(t)+\ldots\right]+ \\
& +\left[w_{0}(t)+\varepsilon w_{1}(t)+\ldots\right] \equiv \\
& \equiv y_{1}(t) e^{\frac{1}{\varepsilon} \int_{0}^{t} \lambda_{1}(x) d x}+y_{2}(t) e^{\frac{1}{\varepsilon} \int_{0}^{t} \lambda_{2}(x) d x}+w(t, \varepsilon) .
\end{aligned}
$$

Let the spectrum stability conditions be violated only at one point:

$$
\lambda_{1}(t)=(t-1) \lambda(t), \quad \lambda(t) \neq 0, \quad \forall t \in[0, T] .
$$

and the condition 2) hold as usual, then instead of the decomposition (2) the following decomposition of the problem (1) will take place:

$$
\begin{aligned}
y(t, \varepsilon)= & v_{\varepsilon}(t)+e^{\frac{1}{\varepsilon} \int_{0}^{t} \lambda_{1}(x) d x} \int_{0}^{t} e^{-\frac{1}{\varepsilon} \int_{0}^{\tau} \lambda_{1}(x) d x} d \tau\left[w_{10}(t)+\varepsilon w_{11}(t)+\ldots\right]+ \\
& +e^{\frac{1}{\varepsilon} \int_{0}^{t} \lambda_{2}(x) d x} \int_{0}^{t} \tau e^{-\frac{1}{\varepsilon} \int_{0}^{\tau} \lambda_{1}(x) d x} d \tau\left[w_{20}(t)+\varepsilon w_{21}(t)+\ldots\right]+ \\
& +\left[w_{30}(t)+\varepsilon w_{31}(t)+\ldots\right] \equiv \varphi_{1} y_{1}(t, \varepsilon)+\varphi_{2} y_{2}(t, \varepsilon)+ \\
& +\sigma_{1}\left(t, \frac{1}{\varepsilon}\right) w_{1}(t, \varepsilon)+\sigma_{2} w_{2}(t, \varepsilon)+w_{3}(t, \varepsilon),
\end{aligned}
$$

where the new type of singularity

$$
\sigma\left(t, \frac{1}{\varepsilon}\right)=e^{\frac{1}{\varepsilon} \int_{0}^{t} \lambda_{1}(x) d x}\left[\int_{0}^{t} e^{-\frac{1}{\varepsilon} \int_{0}^{\tau} \lambda_{1}(x) d x} d \tau+\int_{0}^{t} \tau e^{-\frac{1}{\varepsilon} \int_{0}^{\tau} \lambda_{1}(x) d x} d \tau\right]
$$

gives the main contribution to describe the internal boundary layer

$$
\sigma_{1}\left(t, \frac{1}{\varepsilon}\right) w_{1}(t, \varepsilon)+\sigma_{2}\left(t, \frac{1}{\varepsilon}\right) w_{2}(t, \varepsilon) .
$$

\section{Statement of the problem}

Internal boundary layers in singularly perturbed problems were considered in [3,4] from the standpoint of the regularization method [1,2], in [5-18] from the standpoint of the normal forms method. In this paper the internal boundary layers are investigated in a scalar singularly perturbed problem with fractional derivative:

$$
L_{\varepsilon} y(t, \varepsilon) \equiv \varepsilon y^{(\alpha)}+t y=h(t), \quad y(0, \varepsilon)=y^{0}, \quad t \in[0, T],
$$


where $\varepsilon>0$ is a small parameter, $\alpha=1 / 2, h(t) \in C^{\infty}[0, T]$ is a given known function, $y^{0}$ is a constant number. It is required to find an asymptotic solution of the problem (1) as $\varepsilon \rightarrow+0$.

Singularly perturbed problems with fractional derivatives were studied in [19-22] from the standpoint of the regularization method. In these problems, due to fulfillment of spectrum stability condition, internal boundary layers do not arise. Presence of a singular point at $t=0$ generates an additional singularity in solution of the problem (3), which is not described in terms of limit operator spectrum of the problem (3). By definition of a fractional derivative [23], the derivative $y^{(1 / 2)}$ is denoted as $\sqrt{t} \frac{d y(t, \varepsilon)}{d t}$. Then problem (3) has the following form:

$$
L_{\varepsilon} y(t, \varepsilon) \equiv \varepsilon \sqrt{t} \frac{d y}{d t}+t y=h(t), \quad y(0, \varepsilon)=y^{0} .
$$

\section{Regularization of problem (4)}

We introduce the following regularizing variable:

$$
\tau=-\frac{1}{\varepsilon} \int_{0}^{t} \sqrt{t} d t=-\frac{2}{3 \varepsilon} \sqrt{t^{3}} \equiv p(t, \varepsilon),
$$

and the additional regularizing variable, which takes into account the essentially special singularity, induced by instability of the spectrum at the point $t=0$.

According to the regularization method [1], we must move from the problem (4), the order of which is reduced when $\varepsilon=0$, to some extended problem, which preserves its own order at $\varepsilon=0$. Let us construct the extended problem. If we denote a solution of the extended problem by $\tilde{y}(t, \tau, \sigma, \varepsilon)$, and by $y(t, \varepsilon)$ a solution of the original problem (4), then the following identity holds

$$
\left.\tilde{y}(t, \tau, \sigma, \varepsilon)\right|_{\tau=p(t, \varepsilon), \sigma=q(t, \varepsilon)} \equiv y(t, \varepsilon) .
$$

This identity will be satisfied if the derivatives with respect to of the functions $\tilde{y}(t, \tau, \sigma, \varepsilon)$ and $y(t, \varepsilon)$ will coincide.

Then for the functions $\tilde{y}(t, \tau, \sigma, \varepsilon)$ the following "extended"task corresponds:

$$
\begin{gathered}
\tilde{L}_{\varepsilon} \tilde{y}(t, \tau, \sigma, \varepsilon) \equiv \varepsilon \sqrt{t} \frac{\partial \tilde{y}}{\partial t}-t \frac{\partial \tilde{y}}{\partial \tau}-t \sigma \frac{\partial \tilde{y}}{\partial \sigma}+\varepsilon \sqrt{t} \frac{\partial \tilde{y}}{\partial \sigma}+t \tilde{y}=h(t), \\
\tilde{y}(0,0,0, \varepsilon)=y^{0} .
\end{gathered}
$$

The main advantage of the problem (5) over the task (4) is that its solution $\tilde{y}(t, \tau, \sigma, \varepsilon)$ can be searched in the form of a regular classical series in powers of $\varepsilon$ :

$$
\tilde{y}(t, \tau, \sigma, \varepsilon)=\sum_{k=0}^{\infty} \varepsilon^{k} y_{k}(t, \tau, \sigma),
$$

where $y_{k}(t, \tau, \sigma) \in C^{\infty}[0, T]$, that could not be done for the original problem (4).

Substituting the series (6) into the "extended"problem (5) and equating the coefficients with the same powers of $\varepsilon$, we obtain the following iteration problems:

$$
\begin{aligned}
& L_{0} y_{0}(t, \tau) \equiv-t \frac{\partial y_{0}}{\partial \tau}-t \sigma \frac{\partial y_{0}}{\partial \sigma}+t y_{0}=h(t), \quad y_{0}(0,0,0)=y^{0} \\
& L_{0} y_{1}(t, \tau)=-\sqrt{t} \frac{\partial y_{0}}{\partial t}-\sqrt{t} \frac{\partial y_{0}}{\partial \sigma}, \quad y_{1}(0,0,0)=0 \\
& \ldots \\
& L_{0} y_{k}(t, \tau)=-\sqrt{t} \frac{\partial y_{k-1}}{\partial t}-\sqrt{t} \frac{\partial y_{k-1}}{\partial \sigma}, \quad y_{k}(0,0,0)=0 ; \quad k \geq 2, \\
& \ldots
\end{aligned}
$$




\section{Solvability of iterative problems}

Solutions of the iteration problems $\left(7_{k}\right)$ will be defined in the following space of functions:

$$
U=\left\{y(t, \tau, \sigma): y(t, \tau, \sigma)=y_{0}(t)+y_{1}(t) e^{\tau}+y_{2}(t) \sigma, \quad y_{j}(t) \in C^{\infty}\left([0, T],{ }^{1}\right), j=0,1,2\right\} .
$$

The problem $\left(7_{k}\right)$ has a solution in the space $U$, which can be written in the form:

$$
y_{0}(t, \tau, \sigma)=\alpha_{1}(t) e^{\tau}+\beta_{1}(t) \sigma+h_{0}(t)
$$

where $\alpha_{1}(t), \beta_{1}(t) \in C^{\infty}[0, T]$ are still arbitrary scalar functions, $h_{0}(t)=h(t) / t$. Here expression of the type $h(t) / t$ at the point $t=0$ is understood in the limit sense:

$$
\left[\frac{h(t)}{t}\right]_{t=0}=\lim _{t \rightarrow 0}\left[\frac{h(t)}{t}\right]
$$

To calculate the arbitrary functions $\alpha_{1}(t)$ and $\beta_{1}(t)$ we subject the right-hand side of the equation $\left(7_{1}\right)$ to the orthogonality conditions (see, for example, [1]). We get the equations:

$$
\sqrt{t} \alpha_{1}^{\prime}(t)=0, \quad \sqrt{t} \beta_{1}^{\prime}(t)=0 .
$$

Subjecting (8) to the initial condition $y_{0}(0,0,0)=y^{0}$, we find that

$$
\alpha_{1}(0)=y^{0}-h_{0}(0),
$$

therefore, from the equation (9) the function $\alpha_{1}(t)$ will be defined complitely:

$$
\alpha_{1}(t)=y^{0}-h_{0}(0) .
$$

Now let us calculate the function $\beta_{1}(t)$. From (9) it follows that $\beta_{1}(t)=$ const,

$$
h_{0}(0)+\beta_{1}(0)=0 .
$$

Thus we uniquely find the function:

$$
\beta_{1}(t)=-h_{0}(0),
$$

hence, the solution (8) of the problem $\left(7_{0}\right)$ will be found in the form

$$
y_{0}(t, \tau, \sigma)=\left[y^{0}-h_{0}(0)\right] e^{\tau}-h_{0}(0) \sigma+h_{0}(t) .
$$

Doing here constriction on functions $\tau=p(t, \varepsilon), \sigma=q(t, \varepsilon)$, we obtain the main term of the asymptotics:

$$
\begin{aligned}
& y(t, p(t, \varepsilon), q(t, \varepsilon)) \equiv \\
& \equiv y_{0 \varepsilon}(t)=\left[y^{0}-h_{0}(0)\right] e^{-\frac{2}{3 \varepsilon} \sqrt{t^{3}}}- \\
& \quad-h_{0}(0) e^{-\frac{2}{3 \varepsilon} \sqrt{t^{3}}} \int_{0}^{t} e^{\frac{2}{3 \varepsilon} \sqrt{s^{3}}}+\frac{h(t)}{t} .
\end{aligned}
$$

a solution of the problem (4). The following approximations are calculated in the same way.

We formulate the corresponding result in the form of the following proposition.

Theorem 1. During consistent solution all iteration problems $\left(7_{k}\right)$ are uniquely solvable in the space $U$. 


\section{Numerical results}

Now we find a solution of the problem (4) by using the computer math systems Maple [24]:

$$
\begin{aligned}
& \text { >restart; with(plots); odu: }=(\text { epsilon }) * \operatorname{sqrt}(\mathrm{t}) * \operatorname{diff}(\mathrm{y}(\mathrm{t}), \mathrm{t})+\mathrm{t} * \mathrm{y}(\mathrm{t})=\mathrm{h}(\mathrm{t}) \text {; } \\
& o d u:=\varepsilon \sqrt{t}\left(\frac{d}{d t} \mathrm{y}(t)\right)+t \mathrm{y}(t)=\mathrm{h}(t) \\
& \text { >ins: }=\mathrm{y}(0)=\mathrm{A} \text {; } \\
& >\text { dsolve ([odu,ins]); } \\
& \text { ins }:=\mathrm{y}(0)=A \\
& \mathrm{y}(t)=\left(\int_{0}^{t} \frac{\mathrm{h}\left(\_z 1\right) \mathrm{e}^{\left(\frac{2 z l}{3 \varepsilon}\right)}}{\varepsilon \sqrt{{ }_{-} z 1}} d \_z l+A\right) \mathrm{e}^{\left(-\frac{2 t^{(3 / 2)}}{3 \varepsilon}\right)}
\end{aligned}
$$

Different values of these solutions depending on values of the small parameter $\varepsilon$ and the constant $y^{0}$ are given in the following table:

\begin{tabular}{lcccccc}
\hline & $\mathrm{t}=0$ & $\mathrm{t}=0,2$ & $\mathrm{t}=0,4$ & $\mathrm{t}=0,6$ & $\mathrm{t}=0,8$ & $\mathrm{t}=1$ \\
\hline$\varepsilon=0,010$ & 0 & 0,19557 & 0,39372 & 0,59230 & 0,79110 & 0,99005 \\
$\varepsilon=0,025$ & 0 & 0,18913 & 0,38450 & 0,58094 & 0,77795 & 0,97531 \\
$\varepsilon=0,050$ & 0 & 0,17888 & 0,36962 & 0,56252 & 0,75652 & 0,95125 \\
$\varepsilon=0,075$ & 0 & 0,16927 & 0,35537 & 0,54471 & 0,73573 & 0,92781 \\
$\varepsilon=0,100$ & 0 & 0,16027 & 0,34175 & 0,52754 & 0,71555 & 0,90500 \\
\hline
\end{tabular}

\section{Acknowledgements}

This work is supported by the grant AP05133858 "Contrast structures in singularly perturbed equations and their applications in the theory of phase transitions"Ministry of Education and Science of the Republic of Kazakhstan.

\section{References}

1 Ломов С.А. Введение в общую теорию сингулярных возмущений / С.А. Ломов. - М.: Наука, 1981. - $400 \mathrm{c}$.

2 Ломов С.А. Основы математической теории пограничного слоя / С.А. Ломов, И.С. Ломов. - М.: Изд-во Московск. гос. ун-та. - 2011.

3 Бобочко В.Н. Внутренний пограничный слой / В.Н. Бобочко, С.А. Ломов // Тр. МЭИ. 1980. - 499. - С. 57-60.

4 Елисеев А.Г. Теория сингулярных возмущений в случае спектральных особенностей предельного оператора / А.Г. Елисеев, С.А. Ломов // Матем. сб. - 1986. - 131(173). - № 4. C. 544-557.

5 Иманбаев Н.С. Алгоритм метода регуляризации для сингулярно возмущенной задачи с нестабильным значением ядра интегрального оператора / Н.С. Иманбаев, Б.Т. Калимбетов, М.А. Темирбеков // Вестн. Караганд. ун-та. Сер. Математика. - 2013. - 70, № 4. C. $64-70$ 
6 Калимбетов Б.Т. Математическое описание внутренного пограничного слоя для нелинейной интегро-дифференциальной системы / Б.Т. Калимбетов, Б.И. Ескараева, М.А. Темирбеков // Вестн. Караганд. ун-та. Сер. Математика. - 2014. - 75, № 3. - С. 77-87.

7 Ескараева Б.И. Дискретный пограничный слой в случае нулевых точек спектра для систем интегро-дифференциальных уравнений / Б.И. Ескараева, Б.Т. Калимбетов, М.А. Темирбеков // Вестн. Караганд. ун-та. Сер. Математика. - 2014. - 75, № 3. - С. 88-95.

8 Kalimbetov B.T. Internal boundary layer for integro-differential equations with zero spectrum of the limit operator and rapidly changing kernel. / B.T. Kalimbetov, B.I. Yeskarayeva, A.S. Tolep // Jour. Applied Mathematical Sciences. 2015. - 9, 141-144. - P. 7149-7165.

9 Kalimbetov B.T. Asymptotic solution of singular perturbed problems with an instable spectrum of the limiting operator / B.T. Kalimbetov, M.A. Temirbekov, Zh.O. Habibullaev // Jour. Abstract and Applied Analysis. - 2012. - ID 120192.

10 Kalimbetov B.T. Regularized asymptotical solutions of integro-differential systems with spectral singularites / B.T. Kalimbetov, N.S. Imanbaev, D.A. Sapakov, L.T. Tashimov // Jour. Advances in Difference Equations. - 2012. - 109. doi: 10.1186/1687-1847-2013-109.

11 Kalimbetov B.T. A regularization method for systems with unstable spectral value of the kernel of the integral operator / B.T. Kalimbetov, V.F. Safonov // Jour. Differential Equations. - 1995. - 31(4). - P. 647-656.

12 Safonov V.F. "Splashes" in Fredholm integro-differential equations with rapidly varying kernels / V.F. Safonov, A.A. Bobodzhanov // Math. Notes.- 2009. - 85, 2. - P. 153-167.

13 Сафонов В.Ф. Курс высшей математики. Сингулярно возмущенные задачи и метод регуляризации: учеб. пос. / В.Ф. Сафонов, А.А. Бободжанов. - М.: Издат. дом МЭИ, 2012. $414 \mathrm{c}$.

14 Bobodzhanov A.A. Internal transition layer in a linear optimal control problem / V.F. Safonov, A.A. Bobodzhanov // Jour. Differential equat. - 2001. - 37 (3). - P. 310-322.

15 Калимбетов Б.Т. Нормализованное асимптотическое решение слабо нелинейной сингулярно возмущенной задачи Коши с нестабильным спектром / Б.Т. Калимбетов, В.Ф. Сафонов // Исслед. по интегро-дифф. урав. - Фрунзе: Илим, 1989. - 22. - С. 37-42.

16 Калимбетов Б.Т. Контрастные структуры для линейной задачи со спектральными особенностями на множествах положительной меры / Б.Т. Калимбетов, В.Ф. Сафонов // Узбек. матем. журн. - 2002. - 1. - С. 36-43.

17 Ломов С.А. Алгоритм нормальных форм в нелинейной сингулярно возмущенной системе с нестабильным спектром / С.А. Ломов, В.Ф. Сафонов // Укр. матем. журн. - 1986. 34 (4). - C. $453-644$.

18 Румянцева М.А. Контрастные структуры в линейной сингулярно возмущенной задаче с нестабильным спектром / М.А. Румянцева, В.Ф. Сафонов // Вестн. МЭИ. - 1995. - 6. C. 91-108.

19 Kalimbetov B.T. Regularized asymptotics of solutions for systems of singularly perturbed differential equations of fractional order / B.T. Kalimbetov // Intern. Jour. Fuzzy Math. Archive. 2019. P. 67-74. DOI: http://dx.doi.org/10.22457/ijfma.v16n1a9.

20 Kalimbetov B.T. On the Question of asymptotic integration of singularly perturbed fractionalorder problems / B.T. Kalimbetov // Asian Jour. of Fuzzy and Appl. Math. - 2019. - 6 (3). P. 44-49. DOI: https://doi.org/10.24203/ ajfam.v6:3.5600.

21 Kalimbetov B.T. Regularization Method for Nonlinear Singularly Perturbed Systems of Fractional Order / B.T. Kalimbetov, R. Turgunbaev // Asian Jour. of Fuzzy and Appl. Math. - 2019. 6 (3). - P. 36-43. DOI: https://doi.org/10.24203/ ajfam.v6:3.5598. 
22 Kalimbetov B.T. Scalar Singularly Perturbed Cauchy Problem For a Differential Equation of Fractional Order / B.T. Kalimbetov // Asian Jour. of Fuzzy and Appl. Math. - 2019. - 7 (1). - P. 10-13. DOI: https://doi.org/10.24203/ ajfam..v7i1.5619.

23 Khalil R. A new definition of fractional derivative / A. Khalil, M. Al Horani, A. Yousef, M. Sababheh // Jour. Comput. Appl. Math. - 2014. - 264. - P. 65-70.

24 Dyakonov V.P. Maple 7, Training Course / V.P. Dyakonov. - St. Petersburg. - Piter. - 2003.

Б.Т. Калимбетов, А.Н. Темирбеков, Б.И. Ескараева

\title{
Бөлшек ретті туындылы сингулярлы ауытқыған есепте ішкі шекара қабаты
}

\begin{abstract}
Мақала ішкі шекара қабатын зерттеуге арналған. Мұндай қозғалыстар көбінесе шекара қабатының әсерімен байланысты, яғни төмен ағынның тұтқырлығы ағынды дененің тар париеталды (қабырғалы) қабатына ғана әсер етеді, ал бұл аймақтың сыртында ағын тұтқырлық жоқ - идеалды ағын деп аталады. Шекаралық қабаттағы экспоненталардың саны шекті оператор спектрінің нөлдік емес нүктелерінің санымен анықталды. Мақала авторлары шекті оператор спектрінің бір нүктеде бұзылған жағдайын қарастырған. Есепті зерттеу үшін Ломовтың регуляриация әдісі қолданылған. Бастапқы есептің регуляризациясы жүргізілген және аз тұтқырлық нөлге ұмтылғандағы есептің шешімінің асимптотикасының бас мүшесі құрылған. Тұтқырлықтын әртүрлі мәндері үшін шешімнің сандық нәтижелері алынған.
\end{abstract}

Kiлm сөздер: сингуляр ауытқу, кіші параметр, регуляризация, спектрдің тұрақтылығы, асимптотикалық жинақтылық.

Б.Т. Калимбетов, А.Н. Темирбеков, Б.И. Ескараева

\section{Внутренний пограничный слой в сингулярно возмущенной задаче с производным дробного порядка}

Статья посвящена изучению внутреннего пограничного слоя. Такие движения чаще всего связаны с воздействием пограничного слоя, то есть низкая вязкость потока влияет только в узком париетальном слое обтекаемого тела, а вне этой зоны поток, как если бы не было вязкости, - так называемый идеальный поток. Количество экспонент в пограничном слое определяется количеством ненулевых точек предельного операторного спектра. В статье рассмотрен случай необратимости спектра предельного оператора в одной точке. Для исследования задачи использован метод регуляризации Ломова. Произведена регуляризация исходной задачи, и построен главный член асимптотики решения задачи при стремлении малой вязкости к нулю. Для различных значений малой вязкости получены численные результаты решения.

Ключевые слова: сингулярное возмущение, малый параметр, регуляризация, стабильность спектра, асимптотическая сходимость.

\section{References}

1 Lomov, S.A. (1981). Vvedenie v obshchuiu teoriiu sinhuliarnykh vozmushchenii [Introduction to the general theory of singular perturbations]. Moscow: Nauka [in Russian].

2 Lomov, S.A. \& Lomov, I.S. (2011). Osnovy matematicheskoi teorii pohranichnoho sloia /Foundations of mathematical theory of boundary layer]. Moscow: Izdatelstvo Moskovskoho hosudarstvennoho universiteta [in Russian]. 
3 Bobochko, V.N. \& Lomov, S.A. (1980). Vnutrennii pohranichnyi sloi [Internal boundary layer]. Trudy MEI - The works of MPEI, 499, 57-60 [in Russian].

4 Eliseev, A.G. \& Lomov, S.A. (1986). Teoriia sinhuliarnykh vozmushenii v sluchae spektralnykh osobennostei predelnoho operatora [Theory of singular perturbations in the case of spectral features of the limit operator]. Matematicheskii sbornik - Mathematical collection, 131(173), 4, 544-557 [in Russian].

5 Imanbaev, N.S., Kalimbetov, B.T. \& Temirbekov, M.A. (2013). Alhoritm metoda rehuliarizatsii dlia sinhuliarno vozmushchennoi zadachi s nestabilnym znacheniem yadra intehralnoho operatora [Algorithm the regularization method for a singularly perturbed problem with unstable value of kernel of the integral operator]. Vestnik Karahandinskoho universiteta. Seriia Matematika Vestnik KarSU, Mathematics series, 4, 64-70 [in Russian].

6 Kalimbetov, B.T., Yeskaraeva, B.I. \& Temirbekov, M.A. (2014). Matematicheskoe opisanie vnutrenneho pohranichnoho sloia dlia nelineinoi intehro-differentsialnoi sistemy [Mathematical description of the inner boundary layer for a nonlinear integro-differential system]. Vestnik Karahandinskoho universiteta. Seriia Matematika - Vestnik KarSU, Mathematics series, 75, 3, 77-87 [in Russian].

7 Yeskaraeva, B.I., Kalimbetov, B.T. \& Temirbekov, M.A. (2014). Diskretnyi pohranichnyi sloi $\mathrm{v}$ sluchaie nulevykh tochek spektra dlia sistem intehro-differentsialnykh uravneniy [Discrete boundary layer in the case of zero points of the spectrum for systems of integro-differential equations]. Vestnik Karahandinskoho universiteta. Seriia Matematika - Vestnik KarSU, Mathematics series, 75, 3, 88-95 [in Russian].

8 Kalimbetov, B.T., Yeskarayeva, B.I. \& Tolep A.S. (2015). Internal boundary layer for integrodifferential equations with zero spectrum of the limit operator and rapidly changing kernel. Journal Applied Mathematical Sciences, 9, 141-144, 7149-7165.

9 Kalimbetov, B.T., Temirbekov, M.A. \& Habibullaev, Zh.O. (2012). Asymptotic solution of singular perturbed problems with an instable spectrum of the limiting operator. Journal Abstract and Applied Analysis, ID 120192.

10 Kalimbetov, B.T., Imanbaev, N.S., Sapakov, D.A. \& Tashimov, L.T. (2012). Regularized asymptotical solutions of integro-differential systems with spectral singularites. Journal Advances in Difference Equations, 109, doi: 10.1186/1687-1847-2013-109.

11 Kalimbetov, B.T. \& Safonov, V.F. (1995). A regularization method for systems with unstable spectral value of the kernel of the integral operator. Journal Differential Equations, 31(4), 647656.

12 Safonov, V.F. \& Bobodzhanov, A.A. (2009). "Splashes" in Fredholm integro-differential equations with rapidly varying kernels. Math. Notes, 85, 2, 153-167.

13 Safonov, V.F. \& Bobodzhanov, A.A. (2012). Kurs vysshei matematiki. Sinhuliarno vozmushchennye zadachi $i$ metod rehuliarizatsii [The course of higher mathematics. Singularly pertur-bed problems and regularization method]. Moscow: Publishing House MPEI [in Russian].

14 Bobodzhanov, A.A. \& Safonov, V.F. (2001). Internal transition layer in a linear optimal control problem. Differential equat., 2001, 37 (3), 310-322.

15 Kalimbetov, B.T. \& Safonov, V.F. (1989). Normalizovannye asimptoticheskoe reshenie slabo nelineinoi sinhuliarno vozmushennoi zadachi Koshi s nestabilnym spektrom [Normalized asymptotic solution of a weakly nonlinear singularly perturbed Cauchy problem with an unstable spectrum]. Issledovaniia po intehro-differ. uravneniiam - Research on integro-diff. equations. Frunze: Ilim, 22, 37-42 [in Russian].

16 Kalimbetov, B.T. \& Safonov, V.F. (2002). Kontrastnye struktury dlia lineinoi zadachi so spektralnymi osobennostiami na mnozhestvakh polozhitelnoi mery [Contrast structures for a linear 
problem with spectral features on positive measure sets]. Uzbekskii matematicheskii zhurnal Uzbek. matem. journ., 1, 36-43 [in Russian].

17 Lomov, S.A. \& Safonov, V.F. (1986). Alhoritm normalnykh form v nelineinoi sinhuliarno vozmushennoi sisteme s nestabilnym spektrom [Algorithm normal forms in nonlinear singularly perturbed system with an unstable spectrum]. Ukrainskii matematicheskii zhurnal - Ukr. matem. jour., 34 (4), 453-644 [in Russian].

18 Rumyanceva, M.A. \& Safonov, V.F. (1995). Kontrastnye struktury v lineinoi sinhuliarno vozmushennoi zadache s nestabilnym spektrom [Contrast structures in a linear singularly perturbed problem with an unstable spectrum]. Vestnik MEI - Bulletin MPEI, 6, 91-108 [in Russian].

19 Kalimbetov, B.T. (2019). Regularized asymptotics of solutions for systems of singularly perturbed differential equations of fractional order. Intern. Jour. Fuzzy Math. Archive, 67-74. DOI: http:// dx.doi.org/10.22457/ijfma.v16n1a9.

20 Kalimbetov, B.T. (2019). On the Question of asymptotic integration of singularly perturbed fractional order problems. Asian Jour. of Fuzzy and Appl. Math., 6 (3), 44-49. DOI: https://doi. org/10.24203/ ajfam.v6:3.5600.

21 Kalimbetov B.T. \& Turgunbaev R. (2019). Regularization Method for Nonlinear Singularly Perturbed Systems of Fractional Order. Asian Jour. of Fuzzy and Appl. Math., 6 (3), 36-43. DOI: https://doi.org/10.24203/ ajfam.v6:3.5598.

22 Kalimbetov, B.T. (2019). Scalar Singularly Perturbed Cauchy Problem For a Differential Equation of Fractional Order. Asian Jour. of Fuzzy and Appl. Math., 7 (1), 10-13. DOI: https://doi.org/ 10.24203/ ajfam..v7i1.5619.

23 Khalil, R., Al Horani, M., Yousef, A. \& Sababheh M. (2014). A new definition of fractional derivative. Jour. Comput. Appl. Math., 264, 65-70.

24 Dyakonov, V.P. (2003). Maple 7, Uchebnyi kurs [Maple 7, Training Course]. Saint Petersburg: Piter. 